\title{
The determination of an optimal size for Building Societies' branch offices in South Africa
}

\author{
P.D. Gerber \\ Department of Business Economics, University of South Africa
}

The size of a building society's branch office can have a significant influence on its profitability. In this article a model for an optimal size branch office is established on the basis of three criteria, i.e. the ability of the branch office to generate income, efficiency of labour and control of administrative expenses. A revenue potential index is compiled based on the assumption that revenue potential depends on the volume of funds handled by a branch office. On this basis, weights are allocated, and a ranking order is established for revenue potential according to branch office size. Labour efficiency is measured in terms of average assets con. trolled per employee. Efficient control of administrative ex. penses is evaluated in terms of average administrative ex. penses per employee. From these findings a clear guideline could be established for the optimal branch office size from the profitability viewpoint.

S. Air. J. Bus. Mgmt. 1980, 11: $108-110$

Die grootte van ' $n$ bouvereniging takkantoor kan 'n belangrike invloed op die winsgewendheid daarvan uitoefen. In hierdie artikel word 'n model vir 'n optimale grootte takkantoor aan die hand van drie kriteria bepaal, naamlik die vermoě daarvan om inkomste te genereer, die doeltreffendheid van arbeid, en beheer oor administratiewe uitgawes. 'n Inkomstepoten. siaalindeks word saamgestel op die veronderstelling dat dit afhang van die volume fondse wat deur ' $n$ takkantoor hanteer word. Op grond hiervan word gewigte toegeken en 'n rangorde bepaal vir inkomstepotensiaal volgens takkantoorgrootte. Arbeidsdoeltreffendheid word gemeet in terme van gemiddelde bates per werknemer beheer. Doeltreffende beheer oor administratiewe uitgawes word beoordeel in terme van gemiddelde administratiewe uitgawes per werknemer. Uit hierdie bevindings kon 'n duidelike riglyn vir die optimale takkantoorgrootte uit die winsgewendheidsoogpunt neergele word.

S.Afr. Tydskr. Bedryfst. 1980, 11: $108-110$
There are various factors which can influence the profitability of a building society's branch of fice. Such factors include aspects like management, geographic location and the size of the branch office, to mention a few. Special attention will, however, be paid to only one of these factors, namely the size of the branch office.

Haslem ', in a study on the relative profitability of the branch offices of commercial banks, paid attention to the influence of branch office size. The results of his study indicate that the most favourable size (in terms of return on total capital) is not the largest and also not the smallest branch office. Of the eight sizes of branch offices investigated, the second largest group of branch offices, with total deposits varying between $\$ 50$ million and $\$ 100$ million were the most profitable branch offices. The branch offices which were the most unprofitable, were those with the smallest total deposits of $\$ 1$ million and less. The relation of profitability to the size of the branch offices was of a non-linear nature throughout. Haslem also found, in general terms, that the ability to generate nett income was in favour of the smaller branch offices (mainly as a result of tax considerations), but that the smaller capital ratios of the larger branch offices cancelled this advantage where profitability is measured in terms of return on total capital.

There are various advantages of an increase in capacity which should have an influence on the performance ability of the building society. Silvester states: '. . . perhaps the most obvious advantage of overall size is that derived from the market power that flows from it ${ }^{\prime 2}$.

An example is the financial economies in terms of which it is relatively easier and cheaper for the larger enterprise to draw funds. The financial advantage is realized because the larger enterprises are simply more well-known than the smaller ones, and because they are also in a better position to spread risks. Not one of these factors will necessarily guarantee that the larger enterprise will perform better than the smaller one. Singh and Whittington, ${ }^{3}$ however, have established that there is no relationship between the size of the enterprise and the level of profitability.

Another factor requiring attention is the advantage of an increase in capacity tied to the economic growth of the enterprise. Penrose defines economies of growth as '. . . the internal economies available to an individual firm, which make expansion profitable in particular directions. ${ }^{4}$ Attention should, however, be focussed on 
the fact that the growing enterprise would probably follow a high-capital expansion programme. Growth will probably contribute towards creating a good climate for promotional opportunities and larger employment in the enterprise.

In an unpublished report, Longbrake distinguishes between two types of advantages of capacity increase for branch offices: the first type occurs when the average number of accounts per branch office increases while the number of branch offices remains constant (this type of capacity increase he sees as the economy of branch office size); the second type of advantage of capacity increase develops when the number of branch offices increases while the number of accounts per branch office remains the same. He refers to this position as the economy of the structure of the enterprise.

By taking into account the results of the abovementioned studies, a simple model can be constructed for the determination of an optimal size for a branch office of a typical South African building society.

Three criteria for optimal size are laid down, namely the ability of the branch office to generate income, efficiency of labour and control of administrative expenses.

\section{The empirical investigation}

\section{Introduction}

The empirical data for this investigation were obtained from the branch offices of two of the largest building societies (in terms of total assets). Problems were encountered in obtaining figures from the branch offices of the other building societies, mainly for the following reasons: Various building societies are in the process of computerizing their branch offices, and were reluctant to make available their global figures. In the second place, certain building societies refused to make available confidential figures in respect of their branch offices for strategic reasons. Despite these problems, the figures of 75 branch offices of the two building societies from which figures could be obtained, are regarded as representative of the building society industry with its 353 branch offices in total, thus overcoming the problem.

\section{Revenue potential according to branch office size}

To calculate the revenue potential for the various sizes of branch offices, it was first decided to establish a revenue potential index based on the assumption that the income potential depends on the volume of funds (shares and deposits) handled by such a branch office. The average return of all the building societies was calculated by dividing the nett profit by the total funds handled. In this manner a return of $4 \%$ was calculated.

Table 1 could be compiled to indicate the weighting of each average balance per account, as a contributor to revenue potential of branch offices.

From Table 2 it follows that a branch office with between 51 and 60 staff members has the greatest revenue potential, while the branch office with a staff membership between one to 10 is in second position.

The remaining two criteria for optimal branch office size, namely labour efficiency and administrative expenses, will now be analysed before final conclusions in respect of the optimal size for a building society's branch office can be drawn.
Table 1 Revenue potential according to branch office size

\begin{tabular}{crrr}
\hline $\begin{array}{c}\text { Average balance } \\
\text { of account in } \\
\text { Rand }\end{array}$ & $\begin{array}{c}\text { Central } \\
\text { point }\end{array}$ & $\begin{array}{c}\text { 4\% return } \\
\text { in Rand }\end{array}$ & Weight \\
\hline $0-199$ & 100 & 4 & 0,6 \\
$200-499$ & 350 & 14 & 2,5 \\
$500-999$ & 750 & 30 & 4,6 \\
$1000-1499$ & 1250 & 50 & 7,7 \\
$1500-1999$ & 1750 & 70 & 10,8 \\
$2000-2499$ & 2250 & 90 & 13,8 \\
$2500-2999$ & 2750 & 110 & 16,9 \\
$3000-3499$ & 3250 & 130 & 20,0 \\
$3500-3999$ & 3750 & 150 & 23,1 \\
& & Total 648 & Total 100,0
\end{tabular}

By allocating the weights in Table 1 to each branch office size, the revenue potential of each branch office size can be calculated.

Table 2 Revenue potential according to branch office size based on number of staff

\begin{tabular}{ccc}
\hline $\begin{array}{c}\text { Number of staff in } \\
\text { branch office }\end{array}$ & $\begin{array}{c}\text { Average } \\
\text { Weights* }\end{array}$ & $\begin{array}{c}\text { Rank } \\
\text { Order }\end{array}$ \\
\hline $1-10$ & 34153 & 2 \\
$11-20$ & 13668 & 8 \\
$21-30$ & 12712 & 10 \\
$31-40$ & 14168 & 7 \\
$41-50$ & 15511 & 6 \\
$51-60$ & 46978 & 1 \\
$61-70$ & 11108 & 11 \\
$71-80$ & 7932 & 14 \\
$81-90$ & 9809 & 12 \\
$91-100$ & 13537 & 9 \\
$101-110$ & 16067 & 5 \\
$111-150$ & 4002 & 15 \\
$151-200$ & 18306 & 4 \\
$201-300$ & 8908 & 13 \\
$301-400$ & 19573 & 3 \\
\hline
\end{tabular}

*The average weights were calculated as follows:

(a) Calculate the average balance per account for each branch office size;

(b) Multiply the average balance by the corresponding weight allocated in Table 1;

(c) Add together all the figures obtained in (b) for each branch office size, and divide it by the number of branch offices in that specific group.

\section{Labour efficiency}

The average assets controlled per employee is a very important criterion of labour efficiency in a building society. In Table 3 figures are shown in respect of the average assets controlled per employee at the 75 branch of fices of the same two building societies.

Just as in the case of the revenue potential for the different sizes of branch offices, it follows from Table 3 that there are certain sizes of branch offices where labour, measured in terms of assets controlled per employee, can be applied more efficiently. In the abovementioned table there are three sizes of branch offices which stand out as those at which labour utilization is most efficient, namely at branch of fices with one to 10 employees, 101 to 110 , and 51 to 60 employees in descending order of efficiency. 
Table 3 Average assets controlled per employee

\begin{tabular}{ccc}
\hline $\begin{array}{c}\text { Number of staff } \\
\text { members in branch } \\
\text { office }\end{array}$ & $\begin{array}{c}\text { Average assets } \\
\text { controlled per employee } \\
\text { in Rands }\end{array}$ & $\begin{array}{c}\text { Rank } \\
\text { order }\end{array}$ \\
\hline $1-10$ & 797112 & 1 \\
$11-20$ & 641839 & 5 \\
$21-30$ & 558383 & 11 \\
$31-40$ & 594286 & 8 \\
$41-50$ & 498121 & 14 \\
$51-60$ & 719242 & 3 \\
$61-70$ & 485538 & 15 \\
$71-80$ & 509795 & 13 \\
$81-90$ & 544494 & 12 \\
$91-100$ & 582278 & 9 \\
$101-110$ & 753825 & 2 \\
$111-150$ & 713644 & 4 \\
$151-200$ & 594928 & 7 \\
$201-300$ & 571279 & 10 \\
$301-400$ & 621022 & 6 \\
\hline
\end{tabular}

Although it is realized that various other criteria exist, against which labour efficiency for each branch office size can be tested, the above analysis will suffice because the application of a similar criterion such as the average number of accounts controlled per employee offered the same results.

\section{Administrative expenses}

That administrative expenses play a very important part in the profitability of the building society's branch of fice, and have a very important influence on the size of the optimal branch office, is obvious. In Table 4 the figures of average administrative expenses per employee for the various branch office sizes of the same 75 branch offices used in Tables 2 and 3, are pointed out.

Administrative expenses per staff member were on average the lowest in the branch offices with a staff membership smaller than 10 . The second most favourable branch office size was that with a staff membership of between 41 and 50 members. It is striking that the smaller branch offices, with the exception of the branch offices with a staff membership of between 30 and 40

Table 4 Average administrative expenses per employee

\begin{tabular}{ccc}
$\begin{array}{c}\text { Average number of } \\
\text { staff members in branch } \\
\text { office }\end{array}$ & $\begin{array}{c}\text { Average administrative } \\
\text { expenses per employee } \\
\text { in Rands }\end{array}$ & $\begin{array}{c}\text { Rank } \\
\text { Order }\end{array}$ \\
\hline $1-10$ & 2416 & 1 \\
$11-20$ & 4332 & 3 \\
$21-30$ & 4818 & 4 \\
$31-40$ & 5918 & 8 \\
$41-50$ & 2938 & 2 \\
$51-60$ & 5114 & 5 \\
$61-70$ & 5570 & 7 \\
$71-80$ & 5177 & 6 \\
$81-90$ & 6553 & 9 \\
$91-100$ & 7610 & 10 \\
$101-110$ & 7931 & 14 \\
$111-150$ & 6770 & 12 \\
$151-200$ & 7894 & 13 \\
$201-300$ & 9412 & 15 \\
$301-400$ & 7634 & 11 \\
\hline
\end{tabular}

members, in general managed to keep their administrative expenses on an average lower level. The reason for this probably lies in more efficient control and in the fact that the trained staff member is also expected to perform less important tasks in the smaller branch office.

\section{Conclusions}

Important conclusions can be drawn from the tables in respect of revenue potential, utilization of labour and administrative expenses for the optimal size of a building society branch office. From the 15 different sizes of branch offices against which the abovementioned three criteria were tested, there are especially two sizes which point to an optimal size, namely those with a staff membership of between one and 10 members (most efficient in respect of labour utilization and administrative expenses, with the second best rank order for revenue potential), and those with a staff membership in the group of 41 to 60 members (first in rank order for revenue potential, ranked third for labour utilization and ranked second for administrative expenses.)

The fact that branch offices with a staff membership of one to 10 members indicate such a favourable size in terms of the three criteria, can probably be ascribed to the more effective control at the smaller branch offices in respect of the items labour utilization and administrative expenses. At the larger branch offices (41 to 60 staff members), administrative expenses and labour utilization took the second and third places respectively in the rank order. As far as revenue potential of the different branch office sizes is concerned, it becomes the greatest at the branch office with a staff membership of 51 to 60 members. At the branch of fice with a staff membership of one to 10 members it takes the second place in rank order.

With the abovementioned facts in mind, a guideline can be formulated for the pursuance of an optimal branch office size from the profitability viewpoint. There are two sizes, namely the branch office with a staff membership of between one and 10 members, or between 41 and 60 members. In the extension of a branch office with a staff membership of 10 or fewer members, the objective should be to build up the branch of fice (taking into account market potential) to the second optimal point, namely one with a staff membership of between 41 and 60 members. Should the expansion of a branch office with a staff membership of 60 members be considered, it would be wise to rather consider a sub-branch office with the view to keeping the staff membership down to fewer than 10 members over the short term.

\section{References}

1. Haslem, J.A. A statistical analysis of the relative profitability of Commercial banks, J. Fin., 23, 1, March, 1968, pp. $167-276$.

2. Silvester, A. Economics of scale in theory and practice, Econom. $J ., 82,1972$, p. 388.

3. Singh, A. \& Whittington, G. Growth, profitability and valuation, Dept. of Appl. Econ. Occas. pap., Cambridge University Press, 1968 , p. 119

4. Penrose, E.T. The theory of the growth of the firm, Oxford, Basil Blackwell, 1959, p. 99.

5. Longbrake, W.A. Productive efficiency in commercial banking: the impact of legal form of organisation and size, Federal Deposit Insurance Corporation, unpub. rep. 1973. 